\title{
Telomere Length a Biomarker for Ageing
}

\author{
Mritunjay Kumar Singh ${ }^{1}$, Taruna Gupta ${ }^{2}$ \\ ${ }^{1}$ Research Associate Allele Life Sciences Pvt. Ltd. Noida,U.P. \\ ${ }^{2}$ Research Trainee, Allele Life Science Pvt. Ltd. Noida, U.P.
}

\begin{abstract}
Telomere length in human is emerging as a biomarker of ageing because its shortening is associated with age-related disease. In this review we summarize our current knowledge on the role of telomeres shortening in humans by comparative analysis of TL by using blood samples of different person with different age groups, smokers and non-smokers \& sports and non-sports of same ages with the help of different techniques conventional PCR and RT-PCR.
\end{abstract}

Keywords: Telomere, ageing, senescence, TL (Telomere Length), RT-PCR (Real Time-Polymerase Chain Reaction)

\section{Introduction}

Ageing is the process of becoming older. In broader sense, ageing can refer to single cell within an organism. In human, ageing represents the accumulation of changes in a human being over time, encompassing physical, psychological, and social change. Ageing is among the largest known risk factors for most human diseases. The rate of ageing varies substantially across different species, and this, to a large extent, is genetically based. Every nucleus of a eukaryotic cell is packed with chromosomes, the long, threat-like DNA molecules that carry the genes of living organisms. In the endof the chromosomes there is a region of repetitive nucleoprotein structure called telomeres, which prevent chromosomal ends from end to end fusion and degradation.

Telomeres consist of stretches of repetitive DNA with high guanine and cytosine content. In humans, the telomere terminus consists of $4-15 \mathrm{kbp}$ (bp = base pairs) of the hexanucleotides 5'-TTAGGG-3'. The G-rich DNA strand runs 5 ' to 3 ' toward the terminus and protrudes 100-150 nucleotides beyond the complementary $\mathrm{C}$-rich strand.

Telomere shortening rates can be modified by several lifestyle factors that include mental stress levels, cigarette smoking and dietary intake. Baseline telomere shortening due to the end-replication problem will always exist, but efforts to live a healthy and balanced lifestyle can reduce any additional loss of telomeres. Even poor sleep quality has been associated with shorter telomere lengths in leukocytes among midlife women, independent of perceived psychological stress. There are several factors that causes telomere shortening in a cell. The two most common causes are due to the end-replication problem, and oxidative damage to DNA.

\section{Material and Methods}

\section{1) Sample Collection, Storage}

Blood samples of Smoker \& Non-Smoker Person; Sports \& Non-sports person, Normal person with different age groups varying from 13 to $55 \mathrm{yrs}$. Most in vivo studies of TL in vertebrates' uses blood, for which small samples can be taken routinely and repeatedly from the same individuals, usually with little adverse effect. Importantly, blood cells generally have a high turnover rate
Leading to the expectation and widespread observation of TL loss in blood cells with age and over time. However, blood cells comprise a rich composite of cell types with very different functions, proliferation patterns and levels of telomerase expression.

\section{2) Genomic DNA Isolation from Blood Samples}

Preparation of Chemicals

a) Saturated Phenol

Materials Required:

- Redistilled Phenol, molecular biology grade. (Stored in aliquots at $-20^{\circ} \mathrm{C}$ ).

- 8-hydroxyquinoline

- $0.5 \mathrm{M}$ Tris.Cl buffer ( $\mathrm{pH} 8.0$ )

- 0.1 M Tris.Cl buffer (pH 8.0)

Note: Phenol is volatile and caustic. .

Protocol for preparation of Saturated Phenol:

- Heat a water bath to $65^{\circ} \mathrm{C}$ in the fume hood. Place the bottle of phenol in the fume hood to warm to room temperature.

- Place the bottle of phenol in the $65^{\circ} \mathrm{C}$ water bath to melt the crystals.

- Add 8-hydroxyquinoline to a final concentration of $0.1 \%$ w/v to the phenol. Mix todissolve the 8-hydroxyquinoline.

- Add an equal volume of $0.5 \mathrm{M}$ Tris. $\mathrm{Cl}(\mathrm{pH} \mathrm{8.0)}$ to the phenol. Mix for 15 minutes. Returnthe bottle to the $65^{\circ} \mathrm{C}$ water bath. Allow the phases to separate. Siphon off the top layer and discard. Repeat the procedure as in Step 4 twice

- Add an equal volume of 0.1 M Tris. $\mathrm{Cl}(\mathrm{pH} 8.0)$ to the phenol. Repeat the procedure as in Step 4.

- Repeat the extractions with $0.1 \mathrm{M}$ Tris. $\mathrm{Cl}$ (pH 8.0) until the aqueous phase is $\sim \mathrm{pH} 7.8$ (measure with $\mathrm{pH}$ paper). Repeat the procedure as in Step 4. Leave approx. $\sim 1 \mathrm{~cm}$ layer of $0.1 \mathrm{M}$ Tris. $\mathrm{Cl}(\mathrm{pH} 8.0$ ) over the phenol. Add 2mercaptoethanol to a final concentration of $0.2 \% \mathrm{w} / \mathrm{v}$ to the $0.1 \mathrm{M}$ Tris. $\mathrm{Cl}$ (pH 8.0).

- The buffer saturated phenol may be stored at $4{ }^{\circ} \mathrm{C}$ for 1 month for DNA extraction. Testthe $\mathrm{pH}$ periodically and do not use if the $\mathrm{pH}$ is $<7.5$. 
International Journal of Science and Research (IJSR)

ISSN (Online): 2319-7064

Index Copernicus Value (2015): 78.96 | Impact Factor (2015): 6.391

b) Lysis Buffer

- 50M Tris.cl

- $20 \mathrm{mM}$ EDTA

- $1 \%$ SDS

- $10 \mu \mathrm{L} \beta$-merceptoethanol

c) TE Buffer

- $10 \mathrm{mM}$ Tris

- $1 \mathrm{mM}$ EDTA

Protocol for Genomic DNA Isolation:

- Approximately $250 \mu \mathrm{l}$ of previously separated blood cells were taken in a $700 \mu l$ of lysis buffer. The mixture was incubated at $55^{\circ} \mathrm{C}$ overnight for digestion. Incubated for $37^{\circ} \mathrm{Cfor} 6 \mathrm{hrs}$ with occasion are mixing by gentle swirling in water bath.

- Dissolve solution was centrifuge to separate cell debris at $10000 \mathrm{rpm}$ for 10 minutes.

Aqueous phase was transfer to another tube.

- Equal volume of s-phenol was added to precipitate the protein and centrifuge at $10,000 \mathrm{rpm}$ for 10 minutes. Aqueous phase was taken and transfer to another tube, without disturbing protein complex precipitated as an interphase.

- Equal volume of s-phenol: Chloroform (1:1) was added and centrifuged at $10,000 \mathrm{rpm}$ for

10 minutes to ensure emulsification of the phases. Aqueous phase was transfer to another tube.

- Equal volume of chilled chloroform were added and centrifuged at 10,000 rpm for 10 minutes. Aqueous phase was taken and transfer to another tube.

- $150-170 \mu \mathrm{l}$ of $5 \mathrm{M} \mathrm{NaCl}$ was added to the mixture and double the volume of chilled absolute isopropanol and is allowed to stand for incubation at $-20^{\circ} \mathrm{C}$ for 45 minutes.

- DNA pellete was collected by centrifugation at 10,000 rpm for 10 minutes.

- The tube were inverted and drained on a paper towel. The pellete was washed with $500 \mu \mathrm{l}$ of $70 \%$ ethyl alcohol and centrifuged at $10,000 \mathrm{rpm}$ for 10 minutes. Discard the supernatant and air dried the pellete.

- The pellete was resolved in $50 \mu 1$ of TE buffer.

\section{d) Real Time PCR}

1st step:

- RNA 5 ul

- ddH2O 15 ul

- Incubate at $45^{\circ} \mathrm{C}$ for $600 \mathrm{C}$

- Incubate at $95^{\circ} \mathrm{C}$ for 5 minutes.

- Dilute it with 30ul Nuclease free water.

2nd Step:

RT PCR ABI7000

\begin{tabular}{|c|c|}
\hline Temperature & Time \\
\hline $95^{\circ} \mathrm{C}$ & 5 minutes \\
\hline Loop [ & 35 cycles \\
\hline $95^{\circ} \mathrm{C}$ & 30 seconds \\
\hline $55^{\circ} \mathrm{C}$ & 1 minute \\
\hline $72^{\circ} \mathrm{C}$ & 30 seconds \\
\hline Loop $]$ & \\
\hline $72^{\circ} \mathrm{C}$ & 5 minutes \\
\hline
\end{tabular}

Primers used for RT-PCR

\begin{tabular}{|l|l|}
\hline 36b4 gene & \\
\hline Forward Primer & 5'- TCGAACACCTGCTGGATGAC -3' \\
\hline Reverse Primer & 5'- CCACGCTGCTGAACATGCT -3' \\
\hline
\end{tabular}

Cocktail for RT -PCR

\begin{tabular}{|c|c|}
\hline Components & Quantity (micro-litre) \\
\hline Sybr Green & 12.5 \\
\hline Template cDNA & 1.0 \\
\hline Primer forward & 1.0 \\
\hline Primer reverse & 1.0 \\
\hline Double distilled water & 9.5 \\
\hline
\end{tabular}

Real time thermal cycler program

\begin{tabular}{|c|c|}
\hline Temperature & Time \\
\hline $95^{\circ} \mathrm{C}$ & 10 minutes \\
\hline Loop[ & 40 cycles \\
\hline $95^{\circ} \mathrm{C}$ & 15 seconds \\
\hline $60^{\circ} \mathrm{C}$ & 1 minute \\
\hline Loop $]$ & \\
\hline
\end{tabular}

\section{Result and Discussion}

\section{Qualitative analysis of DNA:}

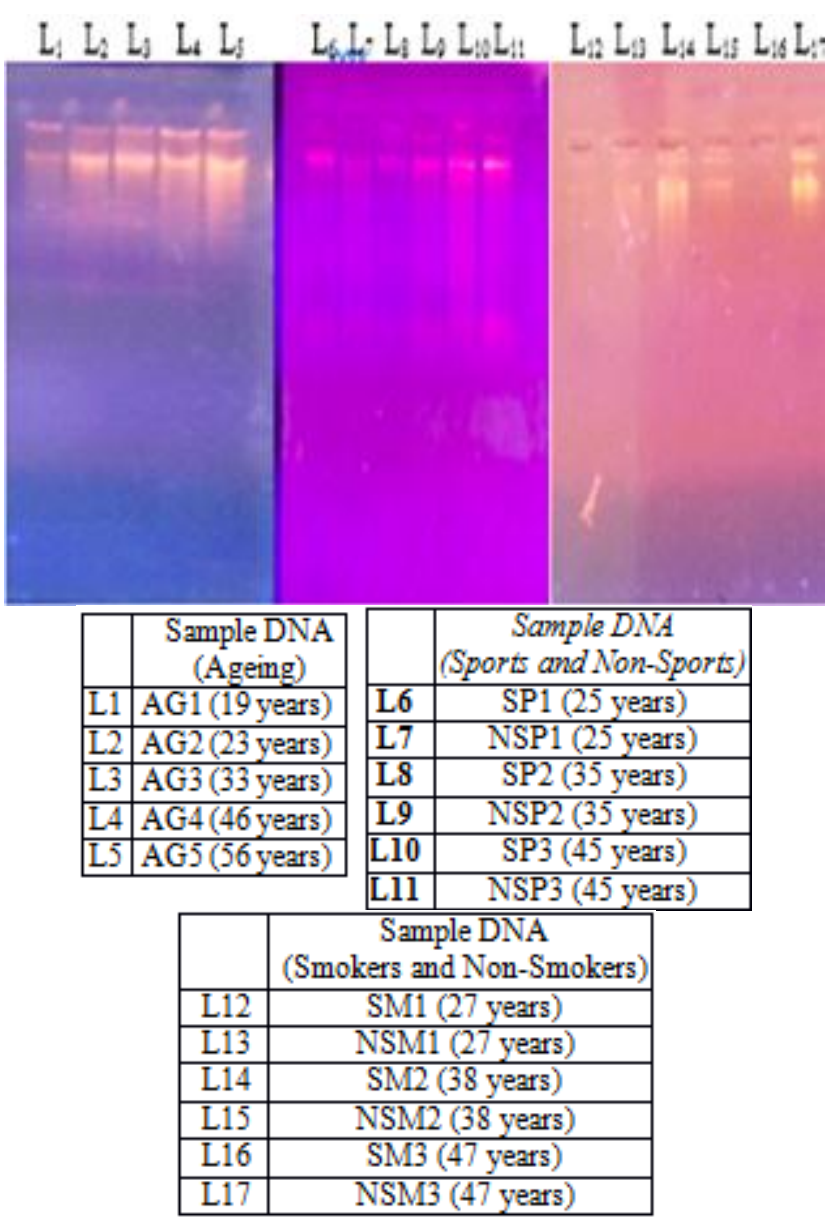

*AG: Ageing blood sample

*SP, NSP: Sports person and Non-sports person respectively

*SM, NSM: Smokers and Non-smoker blood sample 


\section{International Journal of Science and Research (IJSR) \\ ISSN (Online): 2319-7064}

Index Copernicus Value (2015): 78.96 | Impact Factor (2015): 6.391

Quantitative analysis of DNA:

\begin{tabular}{|c|c|c|c|c|}
\hline Sample & $\begin{array}{c}\text { Abs } \\
@ \\
260\end{array}$ & $\begin{array}{c}\text { Abs } \\
\text { @ }\end{array}$ & $\begin{array}{c}\text { Ratio } \\
\text { (OD) }\end{array}$ & $\begin{array}{c}\text { Yield of } \\
\text { DNA } \\
\text { (ug/ul) }\end{array}$ \\
\hline AG1 (19 years) & 0.396 & 0.246 & 1.60 & 1.72 \\
\hline AG2 (23 years) & 0.325 & 0.192 & 1.69 & 1.76 \\
\hline AG3 (33 years) & 0.252 & 0.148 & 1.70 & 1.26 \\
\hline AG4 (46 years) & 0.286 & 0.166 & 1.72 & 1.62 \\
\hline AG5 (56 years) & 0.185 & 0.111 & 1.66 & 1.44 \\
\hline SP1 (25 years) & 0.121 & 0.078 & 1.55 & 1.72 \\
\hline NSP1 (25 years) & 0.194 & 0.121 & 1.60 & 1.76 \\
\hline SP2 (35 years) & 0.235 & 0.131 & 1.79 & 1.26 \\
\hline NSP2 (35 years) & 0.298 & 0.185 & 1.61 & 1.62 \\
\hline SP3 (45 years) & 0.321 & 0.179 & 1.79 & 1.44 \\
\hline NSP3 (45 years) & 0.285 & 0.158 & 1.80 & 1.44 \\
\hline SM1 (27 years) & 0.245 & 0.147 & 1.66 & 1.72 \\
\hline NSM1 (27 years) & 0.421 & 0.245 & 1.71 & 1.76 \\
\hline SM2 (38 years) & 0.325 & 0.198 & 1.64 & 1.26 \\
\hline NSM2 (38 years) & 0.215 & 0.121 & 1.77 & 1.62 \\
\hline SM3 (47 years) & 0.315 & 0.196 & 1.60 & 1.44 \\
\hline NSM3 (47 years) & 0.184 & 0.105 & 1.80 & 1.44 \\
\hline \multicolumn{5}{|l}{} \\
\hline
\end{tabular}

\section{Real Time PCR analysis of Tel1b and Tel2b genes.}

\section{Standard curve for 36B4 (Reference gene)}

36B4 gene is used as single copy gene. SCG (single copy gene) is used as control for amplification of each sample. 36B4 gene encodes acidic ribosomal phosphoprotein P0. For standard curve of 36B4 gene DNA was diluted in different concentration and the reaction was run in real time PCR generating different $\mathrm{Ct}$ value for each dilution. $\mathrm{Ct}$ value increases with decrease in DNA concentration. Concentration of synthesized Oligomer of 36B4 was.......... which was diluted to $1 \mathrm{ng}$ for first dilution and it was further diluted to $2 \mathrm{X}, 4 \mathrm{X}, 8 \mathrm{X}$ and $16 \mathrm{X}$ for standard curve analysis.

Standard curve of 36B4 showed a slope of -3.34 and PCR efficiency of $99.08 \%$.

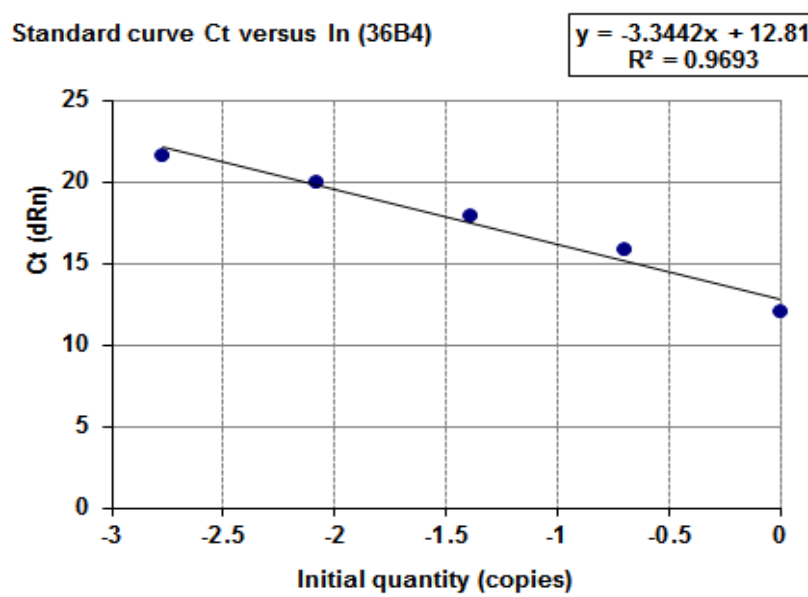

Figure: 36B4 oligomer standard

On the $\mathrm{x}$-axis the logarithm of the genome copy number is displayed, on the y-axis the corresponding $\mathrm{Ct}$ values. The trend line equation is used for calculating 36B4 genome copy number for telomere $\mathrm{Ct}$ values.

\section{Primer sequence for real time PCR}

\section{Conclusion}

Although relying on earlier experiment we performed direct conventional PCR to check comparativelength of telomere, we fail to do so.

In conventional PCR, which DNA sequence will be targeted is a matter of concern. From variousliterature we have come to know that $36 \mathrm{~b} 4$ gene can be targeted to design primer.

Data collected from Real time PCR suggest variations but only in first case i.e. different age group.

Although variation is observed in rest two cases also, data interpretation is not quite satisfactory.

Therefore, we conclude telomere can be used as for biomarker in ageing.

\section{References}

[1] Aviv, A., Hunt, S.C., Lin, J., Cao, X., Kimura, M., and Blackburn, E. (2011). Impartial comparative analysis of measurement of leukocyte telomere length/DNA content by qPCR. Nucleic Acids Res 39, e134.

[2] Haussmann, M.F. \&Mauck, R.A. (2008) new strategies for telomere-based age estimation. Molecular Ecology Resources, 8,264-274.

[3] Pfaffl, M.W. (2001) A new mathematical model for relative quantification in real-time RT-PCR. Nucleic Acids Research, 29, e45.

[4] Zee, R.Y., Castonguay, A.J., Barton, N.S., Germer, S., and Martin, M. (2010). Mean leukocyte telomere length shortening: a case-control study. Transl Res 155, 166169.

[5] O'Callaghan, N.J. \&Fenech, M. (2011). A quantitative PCR method for measuring absolute telomere length. Biological Procedures Online,13:3 